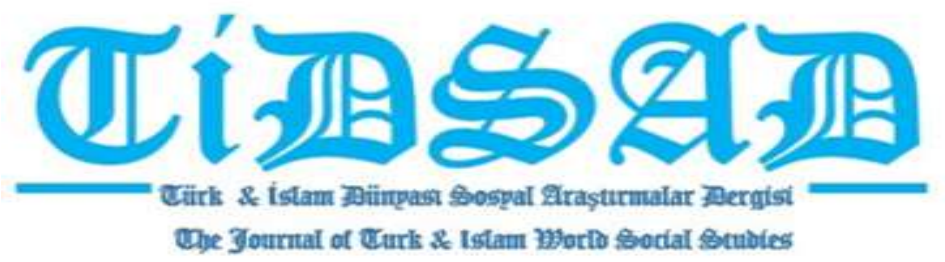

Yll: 6, Sayı: 22, Eylül 2019, s. 219-235

\title{
Mehmet LEVENT
}

İstanbul Aydın Üniversitesi, Uluslararası İktisat Ana Bilim Dalı, Uluslararası İktisat

Bölümü, m_levent44@msn.com

Dr. Öğr Üyesi Çiğdem ÖZARI

İstanbul Aydın Üniversitesi, İktisadi ve İdari Bilimler Fakültesi, Ekonomi Finans Bölümü, cigdemozari@aydin.edu.tr.

\section{EDAS YÖNTEMİ VE KÜMELEME ANALIZİ İLE G-10 ÜLKELERINNIN EKONOMİK ÖZGÜRLÜK KRİTERLERİ İLE DEĞERLENDİRILLMESI ${ }^{1}$}

\section{Özet}

Bu çalışmada G-10 ülkeleri 2017 yılı için, ekonomik özgürlük endeksinde yer alan 12 göstergeden özgürlük ile direk ilişkili olan 6 gösterge dikkate alınarak Çok Kriterli Karar Verme yöntemlerinden biri olan EDAS (Ortalama Çözüm Uzaklığına Dayalı Değerlendirme) yöntemi uygulanarak, ülkeler en iyiden en kötüye sıralanmıştır. Aynı yıl aynı göstergelerle benzer ülkelerin belirlenmesinde ise kümeleme analizinden hiyerarşik olmayan k-ortalamalar yöntemi uygulanarak, G-10'a üye olan 11 ülke 2 kümeye ayrıştırılmıştır. EDAS yönteminden elde edilen sıralama ile k-ortalamalar yönteminden elde edilen benzer küme grupları karşılaştırılarak sonuçların birbiri ile uyumlu olup olmadığı incelenmiştir. Elde edilen bulgularda ise siralamada arka arkaya yer alan bazı ülkelerin, k-ortalamalar yöntemi ile elde edilen kümelerde aynı kümede yer almadığı, bir başka ifade ile birbirine diğer ülkelere oranla 6 gösterge dikkate alındığında daha az benzediği gözlemlenmiştir. Çalışmadaki en önemli amaç EDAS ve k-ortalamalar yönteminin bu alanda da uygulanabilirliğini göstermektir.

Anahtar Kelimeler: Ekonomik Özgürlük, EDAS, Kümeleme Analizi.

${ }^{1}$ EDAS Yöntemi ve Kümeleme Analizi İle G-10 Ülkelerinin Ekonomik Özgürlük Kriterleri İle Değerlendirilmesi: 2007-2017' yüksek lisans tezinden türetilmiştir. 


\title{
EVALUATING ECONOMIC FREEDOM' CRITERIAS of G-10 COUNTRIES WITH EDAS METHOD and CLUSTER ANALYSIS FOR
}

\begin{abstract}
In this research, EDAS method which is one of the of Multiple Criteria Decision Making Methods is applied to G-10 countries for 2017 according to the 6 indices of economic freedom Index. The countries are listed from best to worst. Nonhierarchical k-means method is applied to G-10 members of 11 countries with two clusters. Findings which are obtained from K-means clustering methods EDAS and cluster for specifying the same and similar countries whether the results are compatible with each other or not. According to the findings, it is observed that some sorting countries which are in a row not in the same clusters. In another meaning, it is observed that it is less similar when considering 6 indicators compared to other countries. The most important aim of this research is demonstrating of EDAS and K-means clustering methods are applicable in this field too.
\end{abstract}

Key words: Economic Freedom, EDAS, Cluster Analysis.

\section{GIRISŞ}

Çalışmada Çok Kriterli Karar Verme (ÇKKV) yöntemlerinden EDAS (Ortalama Çözüm Uzaklığına Dayalı Değerlendirme) yöntemi ile kümeleme analizi yöntemlerinden k-ortalamalar yöntemi kullanılmıştır. Bu iki yöntem yardımıyla, G-10 ülkeleri 2017 yılı için ekonomik özgürlük kriterinde yer alan 6 gösterge ile değerlendirilmiştir. Ana amaç EDAS yönteminden elde edilen sıralamanın, k-ortalamalar yönteminden elde edilen küme yapısı ile benzerliğini incelemektir. Bir başka ifade ile ilk sıralarda yer alan ülkelerin aynı kümede yer alıp yer almadığı incelenecektir. Değerlendirme sürecinde kullanılan G-10 ülkelerine üye olan ülkeler Tablo 1'de sunulmuştur.

Tablo 1: G-10 Üye Ülkeleri

\begin{tabular}{ll}
\hline Belçika & Almanya \\
Kanada & İtalya \\
Fransa & Japonya \\
Hollanda & İsveç \\
İsviçre & İngiltere \\
ABD & \\
\hline
\end{tabular}

\section{EDAS VE K-ORTALAMALAR YÖNTEMLERİ}

ÇKKV teknikleri, birbiri ile çelişen birden fazla kriteri karşılayan olası "en iyi/uygun" çözüme ulaşmaya çalışan yaklaşım ve yöntemlerden oluşmaktadır. ÇKKV problemleri, birden fazla kriterin optimize edildiği mümkün olan çözüm setleri içerisinden en iyi alternatifin 
seçildiği problemler olarak da tanımlanabilir (Kılıç, 2016:19). Bir ÇKKV probleminde en iyi çözüme ulaşmak için, farklı ÇKKV yöntemleri kullanabilir. Farklı yöntemler farklı çözümler önerebilir bu nedenle ÇKKV yöntemlerinde pek çok farklı teknik kullanılmaktadır. ÇKKV yöntemlerinin çoğu, karar matrisini kullanarak alternatifler arasında bir tercih sıralaması yapmaktadır. Karar bilimlerinin bir alt dalı olup karar sürecini kriterlere göre modelleme ve analiz etme sürecine dayanan ÇKKV tekniklerinden en çok kullanılan yöntemler TOPSIS, MAUT, SAW ve ELECTRE, Gri İlişkisel Analizdir. Bu çalışmada ise EDAS yöntemi uygulanarak değerlendirme gerçekleştirilerek yöntemin uygulanabilirliği de gösterilmek istenmiştir.

Çok değişkenli istatistiksel bir teknik olan kümeleme analizi yöntemi ise verilerin benzerlikleri bakımından sınıflandırılması ve homojen alt gruplara ayrılması için kullanılmaktadır. K-Ortalamalar yöntemi, en çok bilinen kümeleme yöntemlerinden biri olup hiyerarşik olmayan bir yapıya sahiptir (Fırat ve diğerleri, 2012). Bu çalışmada ÇKKV yöntemlerinden biri olan EDAS yöntemi ve hiyerarşik olmayan K-ortalamalar yönteminden kümeleme analizi uygulanarak bu iki yöntemle elde edilen bulgular birbiri ile karşılaştırılacaktır.

\subsection{EDAS Literatür Taraması}

ÇKKV yöntemlerinden biri olan EDAS, Ghorabaee ve arkadaşları tarafindan geliştirilmiştir. $\mathrm{Bu}$ yöntem 2015 yılında ilk kez envanterlerin gruplandırılması için geliştirilmiş ve aynı zamanda da geçerliliği test edilmiştir (Ghorabaee ve diğ., 2015).

Ghorabaee ve diğerleri (2016) yapmış oldukları çalışmada, kimyasal madde tedarikçisi seçimini bulanık EDAS yöntemi ile değerlendirmişlerdir. Maliyet, teslimat, esneklik, yenilik, kalite ve servis olmak üzere 6 ana kriter ve bu kriterlerle ilişkili alt 14 kriteri dikkate alarak kimyasal malzeme üreten 5 tedarikçi firmayı inceleyerek, içlerinden en uygun olan işletmeyi belirlemişlerdir.

Kahraman ve diğerleri (2017) katı atık imha alanlarının değerlendirilmesi için bulanık EDAS yöntemini uygulamışlardır. Üç alternatif yer içerisinden en uygun katı atık imha alanlarını bulmayı hedefledikleri çalışmada su kirliliği, yerleşim alanlarına uzaklık ve eğim gibi kriterleri dikkate almışlardır.

Stanujkic ve diğerleri (2017) bir inşaat projesinde yer alan 5 müteahhit arasından en iyi müteahhiti belirlemek için Bulanık EDAS yöntemini uygulamışlardır. Uygulamada dikkate aldıkları kriterler ise teknik, finansal, bütünleşik sözleşme ve yönetim, projenin süresidir.

Stević ve diğerleri (2017) ise inşaat firması için tedarikçi seçimini, 6 alternatif arasından 9 kritere göre yine Bulanık EDAS yöntemi ile değerlendirmişlerdir. Malzeme kalitesi, ürünlerin sertifikalandırılması, teslimat süresi, imaj (itibar), hacim indirimleri, garanti süresi, güvenilirlik ve ödeme yöntemi olarak bulanık EDAS yöntemi ile belirlemişlerdir.

Juodagalvienè ve diğerleri (2017) konut plan seçiminde ise EDAS yöntemini kullanmışlardır. Ana yapı elemanların malzeme maliyeti, güvenlik, mekanların ve ara boşlukların yerleşim düzeni, enerji tasarrufu gibi ölçütleri baz alarak 7 adet tek katlı konut arasından en uygun olan konutu belirlemişlerdir. 
Ulutaş (2017) EDAS yöntemini en iyi dikiş makinesi tercihinde kullanmıştır. Yapılan çalışmada ki amaçlardan biri de EDAS yöntemini Türkçe literatürüne tanıtmaktır. Tekstil atölyesinde dikiş makinesi seçimi için kullandığı EDAS yöntemini dikiş hızı, dikiş uzunluğu, fiyat ve enerji kullanımı kriterlerini baz alarak 8 adet dikiş makinesi markasının iyiden kötüye doğru sıralamış ve aralarında en iyi olan dikiş makinesini belirlemiştir.

Ulutaş (2018) EDAS yöntemini Entropi yöntemi ile birlikte uygulayarak lojistik firmalarının performanslarını değerlendirerek çalışmasında en iyi performansın 'Mars' firmasına ait olduğu sonucuna ulaşmıştır.

Ecer (2018) çalışmasında maliyet, ilişki, hizmet, kalite, bilgi sistemi, esneklik, teslimat, profesyonellik, mali durum, konum ve itibar gibi kriterleri dikkate alarak 4 seçenek arasından en uygun firmayı belirlemek için EDAS yöntemini kullanmıştır.

Karabasevic ve diğerleri (2018) çalışmalarında yerli bir şirkette işçi alabilmek için, bilgi teknolojileri alanında uzman 2 kişiyi seçmek üzere ön eleme yoluyla 33 adaydan 6 adaya düşürdükleri elemanları EDAS yöntemi yardımıyla belirlemişlerdir. Çalışmada değerlendirilmeye alınan adaylar; mülakata hazırlık, IT alanındaki eğitim, alanda iş deneyimi, ilişkisel veri tabanı yönetim sistemi özel becerileri ve bilgisi, yabancı dil, kişilerarası becerileri, iletişim ve sunum becerileri gibi kriterleri dikkate almışlardır.

Özbek ve Ergür (2018) çalışmasında Fortune 500'de yer alan ve lojistik sektörüne ait, ulusal ve uluslararası faaliyette bulunan 7 lojistik firmayı EDAS yöntemi ile değerlendirmişlerdir. Dikkate aldıkları kriterler ise bilgi zenginliği, algısal açıklık, dikkat odaklama, işlevlerin görünebilirliği, görsel çekicilik (tasarım), güncellik, içerik, kullanım kolaylığı, online sipariş kabul, ürün kataloğu, yabancı dil seçenekleri, özel misyon ya da web sitesi amaçları web siteleri vb.dir. Elde ettikleri bulgular sonucunda, EDAS yönteminin lojistik firmalarının web sitelerinin değerlendirilmesinde en uygun çözüm olduğu kanısına varmışlardır.

2018 yılında EDAS yöntemi ile yapılan diğer çalışmalar altyüklenici seçimi (Ghorabaee vd., 2018), Hindistan pazarındaki akıllı telefonların değerlendirilmesi (Aggarwal vd., 2018), Elektronik Belge Yönetim Sistemi (EBYS) yazılımı seçimi (Çakır, 2018) olarak karşımıza çıkmaktadır.

Albayrak ve Erkayman (2019) çalışmalarında sporcuların spor aktivitelerini, uyku takibini, sağlık durumlarını kayıt altına alınmasını ve yaşamın elde edilen bu raporlara göre düzenlenmesine yardımcı olan akıllı bileklik seçim sürecini kolaylaştırıp katkı sağlamak amaciyla EDAS yöntemini ÇKKV tekniklerinden Bulanık DEMATEL (Decision Making Trial And Evaluation Laboratory) ile birlikte kullanılmıştır. Çalışmada Bulanık DEMATEL yöntemi kriterler arası ilişkileri baz alarak kriter ağılıklarını saptamak amacı ile kullanılmıştır. Alternatifler arasından seçim yapmak amacıyla ise EDAS yöntemi kullanılmıştır. Bulanık DEMATEL yöntemine göre akıllı bileklik seçiminde en önemli kriterin kullanım kolaylığ olduğu ortaya çıkmıştır. Kullanım kolaylığını sırasıyla, estetik, fonksiyonel özellik, ağırlık ve batarya kullanım süresi izlemiştir. EDAS yönteminin sonuçlarına göre ise 0,924 değerlendirme skoruna sahip akı1lı bileklik en iyi performansa sahiptir.

Özbek (2019) Türkiye'de bulunan illeri; TÜİK'in belirlemiş olduğu altyapı hizmetlerine erişim, çalışma hayatı, çevre, eğitim, gelir, servet, güvenlik, konut, sağlık, sivil katılım, sosyal 
yaşam ve yaşam memnuniyeti ölçütleri dikkate alarak, yaşanabilme noktasında EDAS yöntemi ile birlikte WASPAS yöntemi kullanarak sıralamıştır. Bu çalışmanın neticesinde illerin yaşanabilirlik ölçütlerine göre 8 tane sıralama ortaya çıkmış, yöntemler arasındaki sonuçlar ise 2015 yılında TÜİK'in yayımlamış olduğu Türkiye'deki İller Yaşam Endeksi ile karşılaştırılmıştır.

\subsection{EDAS UYGULAMA}

Çalışmanın bu bölümünde 2017 yılı için G-10 ülkelerinin ekonomik özgürlük endeksinde yer alan 12 kriterden direk özgürlük ile ilişkili 6 kriter dikkate alınarak sıralama gerçekleştirilmiştir. Bu uygulamadaki amaç; 2017 yılında hangi ülke en iyi performans1 göstermiş onu incelemektir. Kriterler ise iş özgürlüğü, işgücü özgürlüğü, parasal özgürlük, ticaret özgürlüğü, yatırım özgürlüğ̈̈ ve finansal özgürlük olarak kısa tanımları ile birlikte Tablo 2'de sunulmuştur.

Tablo 2: Kriter Listesi

\begin{tabular}{|c|l|l|}
\hline Notasyon & Tanım & Açıklama \\
\hline $\mathrm{K}_{1}$ & İş Özgürlüğü & $\begin{array}{l}\text { Bir ülkedeki iş yapma yani işe başlama, işin bulunduğu } \\
\text { faaliyeti ve işi kapatma aşamalarındaki bürokrasi sürecini } \\
\text { ölçmeyi yarayan bir değişkendir }\end{array}$ \\
\hline $\mathrm{K}_{2}$ & İşgücü Özgürlüğü & $\begin{array}{l}\text { Ülkede bulunan işgücü ortamı ile alakalı birçok yasal } \\
\text { düzenlemeyi ççne alan nicel bir ölçüdür. }\end{array}$ \\
\hline $\mathrm{K}_{3}$ & Parasal Özgürlük & Fivat istikrarı ve fivat kontrollerini ele alarak \\
\hline $\mathrm{K}_{4}$ & Ticaret özgürlüğü & $\begin{array}{l}\text { Mal ve hizmetlerin ithalat ve ihracatında etkili olan tarife ve } \\
\text { tarife dı̧ı engellerin varlığının beraber ölçüldüğü bir } \\
\text { değiskendir. }\end{array}$ \\
\hline $\mathrm{K}_{5}$ & Yatırım Özgürlüğü & $\begin{array}{l}\text { Bu değisken ile vabancı vatırım sermavesinin akısındaki } \\
\text { Bu değişken ile ülkedeki bankacılık sisteminin etkisini } \\
\text { ölçmeyi, bunun yanı sıra finansal kesimde hükümetin } \\
\text { denetleme ve müdahalelerine karşı özgürlüğünü göstermeyi } \\
\text { amaçlamaktadır. }\end{array}$ \\
\hline $\mathrm{K}_{6}$ & Finansal özgürlük \\
\hline
\end{tabular}

Kaynak: Çelik, 2015.

EDAS yönteminin adımları, uygulama ile birlikte anlatılacaktır (Keshavarz Ghorabaee ve diğ., 2015).

Adım 1: Karar verici tarafından gerçek değerlerden oluşan karar matrisi $\left(A_{m \times n}\right)$ oluşturulur. Karar matrisinin satırlar alternatifleri (i), sütunlar ise kriterleri (j) gösterir.

$$
A_{m \times n}=\left[a_{i j}\right]=\left[\begin{array}{ccccc}
a_{11} & a_{12} & a_{13} & \ldots & a_{1 n} \\
a_{21} & a_{22} & a_{23} & \ldots & a_{2 n} \\
\ldots & \ldots & \ldots & \ldots & \ldots \\
a_{m 1} & a_{m 2} & a_{m 3} & \ldots & a_{m n}
\end{array}\right]
$$


Çalışmada G-10 ülkeleri 2017 y1lı için, ekonomik özgürlük kriterleri ile inceleneceğinden; karar matrisinin satırlarında en iyiden en kötüye sıralanacak ülkeler yer alırken, karar matrisinin sütunlarında ise ekonomik özgürlük ile ilişkili kriterlerin sayısal değerleri yer alır. Sıralanan ülke sayısı 11, dikkate alınan kriter sayısı 6 olduğundan karar matrisinin satır sayısı 11 sütun sayısı ise 6'dır. Bu bilgiler doğrultusunda karar matrisi Tablo 3'de sunulmuştur.

Tablo 3: Karar Matrisi (2017)

\begin{tabular}{lcccccc}
\hline Ülkeler & $\mathbf{K}_{\mathbf{1}}$ & $\mathbf{K}_{\mathbf{2}}$ & $\mathbf{K}_{\mathbf{3}}$ & $\mathbf{K}_{\mathbf{4}}$ & $\mathbf{K}_{\mathbf{5}}$ & $\mathbf{K}_{\mathbf{6}}$ \\
\hline Belçika & 82 & 61,1 & 84,9 & 87 & 85 & 70 \\
Amerika & 84,4 & 91 & 80,1 & 87,1 & 80 & 70 \\
Birleşik Krallık & 89,9 & 72,8 & 85 & 87 & 90 & 80 \\
Fransa & 78 & 44,1 & 81,6 & 82 & 70 & 70 \\
Hollanda & 80,2 & 70,5 & 85,8 & 87 & 90 & 80 \\
İsveç & 90,8 & 53,2 & 85,3 & 87 & 85 & 80 \\
İsviçre & 76,8 & 72,2 & 84,4 & 90 & 85 & 90 \\
Japonya & 82,3 & 77,5 & 83 & 82,6 & 70 & 60 \\
İtalya & 69,8 & 52,9 & 86,9 & 87 & 85 & 50 \\
Kanada & 81,9 & 73,1 & 77,8 & 88,4 & 80 & 80 \\
Almanya & 86,6 & 42,8 & 85,9 & 87 & 80 & 70 \\
\hline
\end{tabular}

Adım 2: Bu adımda tüm kriter değerlerin ortalaması alınarak ortalama değerler matrisi (AV) oluşturulur.

$$
A V_{j}=\frac{\sum_{i=1}^{n} Y_{i j}}{n}
$$

Yukarıdaki eşitlik yardımı ile ortalama değer matrisi Tablo 4'de sunulmuştur.

Tablo 4: Ortalama Değerler Matrisi (2017)

\begin{tabular}{ccccccc}
\hline & $\mathbf{K}_{\mathbf{1}}$ & $\mathbf{K}_{\mathbf{2}}$ & $\mathbf{K}_{\mathbf{3}}$ & $\mathbf{K}_{\mathbf{4}}$ & $\mathbf{K}_{\mathbf{5}}$ & $\mathbf{K}_{\mathbf{6}}$ \\
\hline Ortalama & 82,0636 & 64,6545 & 83,7000 & 86,5545 & 81,8182 & 72,7273 \\
\hline
\end{tabular}

Adım 3: Her bir kriter için ortalamadan pozitif uzaklık matrisi (PDA) ve ortalamadan negatif uzaklık matrisi (NDA) oluşturulur. Bu matrislerin boyutları karar matrisi ile aynıdır.

$$
\begin{aligned}
P D A & =\left[P A D_{i j}\right]_{m \times n} \\
\boldsymbol{N D A} & =\left[\boldsymbol{N A} \boldsymbol{D}_{\mathrm{I} J}\right]_{\boldsymbol{m} \times \boldsymbol{n}}
\end{aligned}
$$

Eğer maksimum değeri daha iyi yani kriterler faydalı ise aşağıdaki formüller kullanılır. 
Edas Yöntemi ve Kümeleme Analizi İle G-10 ülkelerinin Ekonomik Özgürlük Kriterleri İle Değerlendirilmesi

$$
P D A_{i j}=\frac{\operatorname{mak}\left(0,\left(Y_{i j}-A V_{j}\right)\right)}{A V_{j}} \text { ve } N D A_{i j}=\frac{\operatorname{mak}\left(0,\left(A V_{j}-Y_{i j}\right)\right)}{A V_{j}}
$$

Eğer kriterlerin minimum değeri daha iyiyse yani faydalı değil ise aşăğdaki formüller kullanılır.

$$
P D A_{i j}=\frac{\operatorname{mak}\left(0,\left(A V_{j}-Y_{i j}\right)\right)}{A V_{j}} \text { ve } N D A_{i j}=\frac{\operatorname{mak}\left(0,\left(Y_{i j}-A V_{j}\right)\right)}{A V_{j}}
$$

Pozitif uzaklık matrisi ve negatif uzaklık matrisi sırasıyla Tablo 5 ve Tablo 6'da sunulmuştur.

Tablo 5: Pozitif Uzaklık Matrisi (2017)

\begin{tabular}{lcccccc}
\hline Ülkeler & $\mathbf{K}_{\mathbf{1}}$ & $\mathbf{K}_{\mathbf{2}}$ & $\mathbf{K}_{\mathbf{3}}$ & $\mathbf{K}_{\mathbf{4}}$ & $\mathbf{K}_{\mathbf{5}}$ & $\mathbf{K}_{\mathbf{6}}$ \\
\hline Belçika & 0,0000 & 0,0000 & 0,0143 & 0,0051 & 0,0389 & 0,0000 \\
Amerika & 0,0285 & 0,4075 & 0,0000 & 0,0063 & 0,0000 & 0,0000 \\
Birleşik Krallık & 0,0955 & 0,1260 & 0,0155 & 0,0051 & 0,1000 & 0,1000 \\
Fransa & 0,0000 & 0,0000 & 0,0000 & 0,0000 & 0,0000 & 0,0000 \\
Hollanda & 0,0000 & 0,0904 & 0,0251 & 0,0051 & 0,1000 & 0,1000 \\
İsveç & 0,1065 & 0,0000 & 0,0191 & 0,0051 & 0,0389 & 0,1000 \\
İsviçre & 0,0000 & 0,1167 & 0,0084 & 0,0398 & 0,0389 & 0,2375 \\
Japonya & 0,0029 & 0,1987 & 0,0000 & 0,0000 & 0,0000 & 0,0000 \\
İtalya & 0,0000 & 0,0000 & 0,0382 & 0,0051 & 0,0389 & 0,0000 \\
Kanada & 0,0000 & 0,1306 & 0,0000 & 0,0213 & 0,0000 & 0,1000 \\
Almanya & 0,0553 & 0,0000 & 0,0263 & 0,0051 & 0,0000 & 0,0000 \\
\hline
\end{tabular}

Tablo 6: Negatif Uzaklık Matrisi (2017)

\begin{tabular}{lcccccc}
\hline Ülkeler & $\mathbf{K}_{\mathbf{1}}$ & $\mathbf{K}_{\mathbf{2}}$ & $\mathbf{K}_{\mathbf{3}}$ & $\mathbf{K}_{\mathbf{4}}$ & $\mathbf{K}_{\mathbf{5}}$ & $\mathbf{K}_{\mathbf{6}}$ \\
Belcika & 0,0008 & 0,0550 & 0,0000 & 0,0000 & 0,0000 & 0,0375 \\
Amerika & 0,0000 & 0,0000 & 0,0430 & 0,0000 & 0,0222 & 0,0375 \\
Birleșik Krallık & 0,0000 & 0,0000 & 0,0000 & 0,0000 & 0,0000 & 0,0000 \\
Fransa & 0,0495 & 0,3179 & 0,0251 & 0,0526 & 0,1444 & 0,0375 \\
Hollanda & 0,0227 & 0,0000 & 0,0000 & 0,0000 & 0,0000 & 0,0000 \\
İsvec & 0,0000 & 0,1772 & 0,0000 & 0,0000 & 0,0000 & 0,0000 \\
İsviçre & 0,0641 & 0,0000 & 0,0000 & 0,0000 & 0,0000 & 0,0000 \\
Japonya & 0,0000 & 0,0000 & 0,0084 & 0,0457 & 0,1444 & 0,1750 \\
İtalya & 0,1494 & 0,1818 & 0,0000 & 0,0000 & 0,0000 & 0,3125 \\
Kanada & 0,0020 & 0,0000 & 0,0705 & 0,0000 & 0,0222 & 0,0000 \\
Almanya & 0,0000 & 0,3380 & 0,0000 & 0,0000 & 0,0222 & 0,0375 \\
\hline
\end{tabular}


Edas Yöntemi ve Kümeleme Analizi İle G-10 ülkelerinin Ekonomik Özgürlük Kriterleri İle Değerlendirilmesi

Adım 4: Karar matrisindeki tüm alternatifler için (i) ağılıklı toplam pozitif $\left(S P_{i}\right)$ ve ağırlıklı toplam negatif $\left(S N_{i}\right)$ değer hesaplanır.

$\mathrm{Bu}$ değerler aşağıda belirtilen eşitlik yardımı ile bulunmaktadır.

$$
S P_{i}=\sum_{j=1}^{m} w_{j} \times P D A_{i j} \text { ve } S N_{i}=\sum_{j=1}^{m} w_{j} \times N D A_{i j}
$$

$w_{j}: \mathrm{j}$. Değerlendirme faktörünün (kriterin) önem derecesi (ă̆ırlı̆̆

Kriterlerin önem değerleri bilinmediğinden, önem dereceleri yani ağırlıkları eşit olarak ele alınmıştır. Önem derecelerinin farklı yöntemlerle belirlenerek yapılan çalışmalarda farklı sonuçlar elde edilebileceği aşikârdır. Tablo 7 ve Tablo 8'de sırasıyla, her alternatif (i) için $S P_{i}$ ve $S N_{i}$ değerleri yer sunulmuştur

Tablo 7: Ağırlıklı Toplam Pozitif Değerler (2017)

\begin{tabular}{llllllll}
\hline Ülkeler & $\mathbf{K}_{\mathbf{1}}$ & $\mathbf{K}_{\mathbf{2}}$ & $\mathbf{K}_{\mathbf{3}}$ & $\mathbf{K}_{\mathbf{4}}$ & $\mathbf{K}_{\mathbf{5}}$ & $\mathbf{K}_{\mathbf{6}}$ & $\boldsymbol{S P}_{\boldsymbol{i}}$ \\
\hline Belcika & 0,0000 & 0,0000 & 0,0024 & 0,0009 & 0,0065 & 0,0000 & 0,0097 \\
Amerika & 0,0047 & 0,0679 & 0,0000 & 0,0011 & 0,0000 & 0,0000 & 0,0737 \\
Birlesik Krallık & 0,0159 & 0,0210 & 0,0026 & 0,0009 & 0,0167 & 0,0167 & 0,0737 \\
Fransa & 0,0000 & 0,0000 & 0,0000 & 0,0000 & 0,0000 & 0,0000 & 0,0000 \\
Hollanda & 0,0000 & 0,0151 & 0,0042 & 0,0009 & 0,0167 & 0,0167 & 0,0534 \\
İsvec & 0,0177 & 0,0000 & 0,0032 & 0,0009 & 0,0065 & 0,0167 & 0,0449 \\
İsviçre & 0,0000 & 0,0195 & 0,0014 & 0,0066 & 0,0065 & 0,0396 & 0,0735 \\
Japonva & 0,0005 & 0,0331 & 0,0000 & 0,0000 & 0,0000 & 0,0000 & 0,0336 \\
İtalya & 0,0000 & 0,0000 & 0,0064 & 0,0009 & 0,0065 & 0,0000 & 0,0137 \\
Kanada & 0,0000 & 0,0218 & 0,0000 & 0,0036 & 0,0000 & 0,0167 & 0,0420 \\
Almanya & 0,0092 & 0,0000 & 0,0044 & 0,0009 & 0,0000 & 0,0000 & 0,0145 \\
\hline
\end{tabular}

Tablo 8: Ağırlıklı Toplam Negatif Değerler (2017)

\begin{tabular}{lccccccc}
\hline \multicolumn{1}{c}{ Ülkeler } & $\mathbf{K}_{\mathbf{1}}$ & $\mathbf{K}_{\mathbf{2}}$ & $\mathbf{K}_{\mathbf{3}}$ & $\mathbf{K}_{\mathbf{4}}$ & $\mathbf{K}_{\mathbf{5}}$ & $\mathbf{K}_{\mathbf{6}}$ & $\boldsymbol{S N}_{\boldsymbol{i}}$ \\
\hline Belcika & 0,0001 & 0,0092 & 0,0000 & 0,0000 & 0,0000 & 0,0063 & 0.0155 \\
Amerika & 0,0000 & 0,0000 & 0,0072 & 0,0000 & 0,0037 & 0,0063 & 0,0171 \\
Birleșik Krallık & 0,0000 & 0,0000 & 0,0000 & 0,0000 & 0,0000 & 0,0000 & 0,0000 \\
Fransa & 0,0083 & 0,0530 & 0,0042 & 0,0088 & 0,0241 & 0,0063 & 0,1045 \\
Hollanda & 0,0038 & 0,0000 & 0,0000 & 0,0000 & 0,0000 & 0,0000 & 0,0038 \\
İsvec & 0,0000 & 0,0295 & 0,0000 & 0,0000 & 0,0000 & 0,0000 & 0,0295 \\
İsviçre & 0,0107 & 0,0000 & 0,0000 & 0,0000 & 0,0000 & 0,0000 & 0,0107 \\
Japonya & 0,0000 & 0,0000 & 0,0014 & 0,0076 & 0,0241 & 0,0292 & 0,0622 \\
İtalya & 0,0249 & 0,0303 & 0,0000 & 0,0000 & 0,0000 & 0,0521 & 0,1073 \\
Kanada & 0,0003 & 0,0000 & 0,0117 & 0,0000 & 0,0037 & 0,0000 & 0,0158
\end{tabular}




\section{\begin{tabular}{llllllll} 
Almanva & 0,0000 & 0,0563 & 0,0000 & 0,0000 & 0,0037 & 0,0063 & 0,0663 \\
\hline
\end{tabular}}

Adım 5: Bulunan bütün $S P_{i}$ ve $N P_{i}$ alternatif değerleri aşağıda gösterilen formül ile normalize edilir.

$$
N S P_{i}=\frac{S P_{i}}{\max _{i}\left(S P_{i}\right)} \text { ve } N S N_{i}=1-\frac{S N_{i}}{\max _{i}\left(S N_{i}\right)}
$$

Tablo 9'da ağırlıklı pozitif ve negatif değerlerin normalize değerleri ülke bazlı gösterilmektedir.

Tablo 9: Ağırlıklı Pozitif ve Negatif Değerlerin Normalize Değerleri (2017)

\begin{tabular}{|c|c|c|}
\hline Ülkeler & $\boldsymbol{N S P}_{\boldsymbol{i}}$ & $\boldsymbol{N S N}_{\boldsymbol{i}}$ \\
\hline Belçika & 0,1320 & 0,8404 \\
\hline Amerika & 1 & 1 \\
\hline Birleşik Krallık & 0,9998 & 0,0259 \\
\hline Fransa & 0,0000 & 0,9647 \\
\hline Hollanda & 0,7250 & 0,7248 \\
\hline İsvec & 0,6096 & 0,9004 \\
\hline İsvicre & 0,9978 & 0,4198 \\
\hline Japonva & 0,4558 & 0,0000 \\
\hline İtalva & 0,1860 & 0,8529 \\
\hline Kanada & 0,5697 & 0,3821 \\
\hline Almanya & 0,1961 & 0,0000 \\
\hline
\end{tabular}

Adım 6: Son adım olarak normalize edilmiş her alternatif için değerlendirme skorları $\left(A S_{i}\right)$ aşağıda belirtilen eşitlik ile bulunur ve $A S_{i} 0$ (dahil) ile 1 (dahil) arasında değerler alır.

$$
A S_{i}=\frac{1}{2} \times\left(N S P_{i}+N S N_{i}\right)
$$

En büyük değerlendirme skoruna sahip alternatif en iyi alternatif olarak belirlenir. Tablo 10'da tüm ülkelerin değerlendirme skorları ile birlikte ülkelerin sıralaması sunulmuştur.

Tablo 10: Ülkelerin Performans Değerlendirme Skorları (2017)

\begin{tabular}{cccc}
\hline Ülkeler & $\boldsymbol{N S P}_{\boldsymbol{i}}$ & $\boldsymbol{N S N}_{\boldsymbol{i}}$ & Değerlendirme Skoru \\
\hline Belçika & 0,1320 & 0,8404 & 0,4862 \\
Amerika & 1,0000 & 1,0000 & 1,0000 \\
Birleşik Krallık & 0,9998 & 0,0259 & 0,5128 \\
Fransa & 0,0000 & 0,9647 & 0,4824 \\
Hollanda & 0,7250 & 0,7248 & 0,7249 \\
İsveç & 0,6096 & 0,9004 & 0,7550
\end{tabular}




\begin{tabular}{cccc} 
İsviçre & 0,9978 & 0,4198 & 0,7088 \\
Japonya & 0,4558 & 0,0000 & 0,2279 \\
İtalya & 0,1860 & 0,8529 & 0,5195 \\
Kanada & 0,5697 & 0,3821 & 0,4759 \\
Almanya & 0,1961 & 0,0000 & 0,0980 \\
\hline
\end{tabular}

Tablo 11'de ise sıralamanın daha düzgün değerlendirilmesi için değerlendirme skorları ile birlikte ülkeler en iyiden en kötüye doğru sıralanarak sunulmuştur.

Tablo 11: Ülkelerin Performans Değerlendirme Sıralaması (2017)

\begin{tabular}{ccc}
\hline Değerlendirme Skoru & Sıralama & Ülkeler \\
\hline 1,0000 & 1 & Amerika \\
0,7550 & 2 & İsveç \\
0,7249 & 3 & Hollanda \\
0,7088 & 4 & İsviçre \\
0,5195 & 5 & İtalya \\
0,5128 & 6 & Birleşik Krallık \\
0,4862 & 7 & Belçika \\
0,4824 & 8 & Fransa \\
0,4759 & 9 & Kanada \\
0,2279 & 10 & Japonya \\
0,0980 & 11 & Almanya \\
\hline
\end{tabular}

\subsection{K-Ortalamalar Literatür Taraması}

K-ortalamalar kümeleme analizi bir veri setindeki nesneleri ortak özellikleri itibariyle gruplandırma ya da küme olarak adlandırılan alt veri setlerine ayırma işlemidir (Liu ve ark., 2010). Kümeleme işlemi ile bir kümede bulunan nesnelerin mümkün olduğunca birbirine benzer, ancak diğer kümelerdekinden mümkün olduğunca farklı olması amaçlanır. Bir başka deyişle küme içindeki varyansın düşük, kümeler arasındaki varyansların ise yüksek olması arzulanmaktadır. Kümeleme analizi herhangi bir alan içerisindeki verileri gruplandırarak, benzerlikleri bakımından sınıflandırıp o gruplar arasında karşılaştırma yapmak amacı ile kullanılan bir tekniktir.

Hamarat (1998) Türkiye'de ki illeri sağlık, nüfus, ekonomik ve kültürel endekslerine göre kümeleme analizi yöntemine göre sınıflandırmıştır. Bu çalışmada 30 endeks parametresi vardır.

Çalışmanın sonucunda elde edilen en önemli sonuçlardan biri Ward kümeleme yönteminin Karasel Öklid Uzaklığına göre verdiği sonuçla kümele analizi tekniklerinden en uygun sonuç olduğu yönündedir. Sonuç olarak şehirler 8 alt küme olarak birbirinden ayrılmıştır. 
Şehirlerin uygun şekilde seçilip seçilmediğinin belirlenmesinde, kümelenme analizi ayırma analizini uygulamış ve şehirlerin pozitif bir düzende gruplandırıldığı ve parametrelerin ayrımcılıkta önemli bir rol oynadığı sonucuna varmıştır.

Yüksel (2002) çalışmasında, dondurulmuş hazır yemekler satın alan tüketicilerin belirli özelliklere sahip bölümlerde toplanıp toplanmadığını kümeleme analizi ile incelemiştir. Dondurulmuş hazır yemek satın alan ve kullananların; satın alma nedenlerinin 4 segment oluşturdukları sonucuna varmıştır.

Demirel (2004) çalışmasında, Türkiye akarsu havzalarının gruplandırılmasını ve birbirine benzer özelliklere ait yerlerin belirlenmesini hiyerarşik kümeleme yöntemini kullanarak gerçekleştirmiştir.

Arslan (2004) çalışmasında, etkili bir spor ayakkabı pazarını oluşturabilmek adına tüketici bölümlerinin oluşturulmasında çok boyutlu bir yaklaşım önerisinde bulunmuş ve bu amaç doğrultusunda oluşturduğu verilere kümeleme analizi ve ayırma analizi uygulamıştır. Böylece tüketici bölümleri oluşturulduğu sonucuna varmıştır.

Turan (2005) çalışmasında ise Ward yöntemi (en küçük varyans) ile Türkiye'de bulunan akarsu verimliliklerini sınıflandırmıştır.

Kahya (2007) çalışmasında, Türkiye'deki akarsu akımlarının konumsal olarak sınıflandırılmasında K-ortalamalar yöntemini kullanmıştır.

Demirel (2007) çalışmasında, K-ortalamalar yöntemini Türkiye akarsu havzalarındaki temel kuraklık bileşenlerinin sınıflandırılması için kullanmıştır.

Aşan (2007) çalışmasında, kümeleme analizi kullanarak kredi kartı kullanan banka müşterilerini sosyoekonomik özelliklerine göre gruplandırmıştır.

Isik ve Singh (2009) çalışmalarında, aylık olarak ortalama akım verilerini göz önüne alarak Ward ve K- ortalamalar yöntemlerini kullanarak Türkiye havzalarını sınıflandırmış, dikkate aldığı verilere göre yaptığı kümeleme analizi sonucunda küme sayısını 7 olarak belirlemişlerdir.

Ersöz (2009) çalışmasında daha önceki yapılan başka bir çalışmada belirlenen 4 sağlık kriterine göre OECD ülkelerinin önemini ortaya çıkarmak amacıyla; ülkeleri gruplandırılması ve karşılaştırılması için kümeleme yöntemi ve ayırma analizi yöntemlerinden yararlanmıştır.

Helgesen ve diğerleri (2009) çalışmalarında pazarlama alanındaki tecrübesiz elemanların algıları ve iş performansları arasındaki ilişkiyi kümeleme analizi yöntemi ile değerlendirmişlerdir.

Fırat ve diğerleri (2012) çalışmalarında yıllık yağış miktarını gruplandırmayı ve böylelikle homojen yerleri belirlemeyi, K-ortalamalar yöntemini kullanarak gerçekleştirmişlerdir.

Cengiz ve Öztürk (2012) çalışmalarında, Türkiye'de il eğitim düzeyinin benzerliğini belirlemek için küme analiz yöntemi uygulamışlardır. Çalışmalarında, okuma yazma bilmeyen, okuyabilen ve yazabilen ancak ilk, orta, yüksek öğrenim, derece gibi bir okulu bitiremeyen eğitim gibi temel alan birçok rapor bulunmaktadır. 
Çelik (2013) çalışmasında 81 ile ait 10 sağlık değişkeni ile benzer yapıyı gösteren il gruplarını kümeleme analizi ile belirlemiştir. Çalışmadan elde edilen bulgular, her il için yeterli sayıda hastane kurulmasının, kurulan hastanelere nüfus, gelişmişlik ve sosyoekonomik kriterlerine göre doktor, diş hekimi ve diğer sağlık işçilerinin tayininin organize bir düzende yapılmasının, özel hastaneleri özendirerek diğer şehir hastanelerinin yatak kapasitelerinin ve cihaz sayılarının yükseltmeleri zorunda olduğu yönündedir.

\subsection{K-Ortalamalar Uygulama (2017)}

K-ortalamalar kümeleme yönteminin adımları aşağıdaki gibidir (Karypis ve diğerleri, 2000);

Adım 1: Ayrıştırılmak istenen küme sayısını belirle

Adım 2: Başlangıç küme merkezleri olarak k tane nesne belirle,

Adım 3: Her nesneyi, küme merkezi kendine en yakın olan kümeye ata,

Adım 4: Tüm nesneler atandığında, küme ortalamalarını hesaplayarak, k adet merkez nesneleri yeniden hesapla,

Adım 5: Adım 3 ve Adım 4'ü küme elemanları sabitleninceye kadar tekrar et.

K-ortalamalar yönteminin ilk adımı ayrıştırmak istenen küme sayısının belirlenmesidir. Bu çalışmada G-10 ülkelerini iki kümeye ayırarak EDAS yönteminden elde edilen sonuçlarla karşılaştırmak hedeflenmiştir. Yöntemin ikinci adımında ise küme merkezlerini temsil etmek amacıyla rastgele iki başlangıç merkez veri seçilmesidir. Bu çalışmada başlangıç küme merkezi olarak veri seti içinden olası tüm ikili değerler ele alınarak analiz tekrarlanmıştır. Bir başka ifade ile veri seti 11 ülkenin 6 ekonomik özgürlük kriter değerlerini ifade ettiğinden, başlangıç merkezi olarak 11 ülkeden tüm olası iki ülke seçilerek analiz tekrarlanmıştır. Analizlerden elde edilen farklı tüm küme grupları, bu küme gruplarının hangi başlangıç merkez verilerden elde edildiği ve görülme sıklıkları Tablo 12'de sunulmuştur. 55 kere gerçekleşen k-ortalamalar analizi sonucunda 11 farklı küme grubu gözlemlenmiştir. En sık gözlemlenen küme grubunda Almanya, Belçika, Fransa, İsveç, İtalya bir kümede yer alırken diğer ülkeler ise diğer kümede yer almaktadır.

Tablo 12: Kümeleme Analizi Sonuçları (2017)

\begin{tabular}{|c|c|c|c|c|}
\hline No & Küme 1 & Küme 2 & $\begin{array}{c}\text { Veri Seti İçinden Başlangıç } \\
\text { Merkezler }\end{array}$ & Sıklık \\
\hline 1 & $\begin{array}{l}\text { Almanya, Belçika, } \\
\text { Fransa, İsveç, İtalya }\end{array}$ & $\begin{array}{c}\text { Amerika, } \\
\text { B.Krallık, } \\
\text { Hollanda, } \\
\text { İsviçre, } \\
\text { Japonya, } \\
\text { Kanada }\end{array}$ & $\begin{array}{c}\text { (Belçika, Fransa) (Belçika, İsveç) } \\
\text { (Belçika, Kanada) (Belçika, } \\
\text { Almanya) } \\
\text { (Amerika, Fransa) (Amerika, } \\
\text { İtalya) (Amerika, Almanya) } \\
\text { (B.Krallı, İsveç) (B.Krallı, } \\
\text { İsviçre) } \\
\text { (B.Krallık, Almanya) (Fransa, } \\
\text { İsviçre) (Fransa, Japonya) }\end{array}$ & 19 \\
\hline
\end{tabular}




\begin{tabular}{|c|c|c|c|c|}
\hline & & & $\begin{array}{l}\text { (Hollanda, İsveç) (Hollanda, } \\
\text { Almaya) (İsveç, İsviçre) (İsveç, } \\
\text { Kanada) (İsviçre, Almanya) } \\
\text { (Japonya, Almanya) } \\
\text { (Kanada, Almanya) }\end{array}$ & \\
\hline 2 & $\begin{array}{c}\text { Amerika, Belçika, } \\
\text { B.Krallık, Hollanda, } \\
\text { İsveç, İsviçre, Japonya, } \\
\text { Kanada }\end{array}$ & $\begin{array}{l}\text { Almanya, } \\
\text { Fransa, İtalya }\end{array}$ & $\begin{array}{c}\text { (B.Krallık, Hollanda) } \\
\text { (B.Krallık, İtalya) (Fransa, } \\
\text { Hollanda) (Fransa, Kanada) } \\
\text { (Hollanda, İtalya) (İsveç, Almanya) } \\
\text { (Japonya, İtalya) (İtalya, Kanada) }\end{array}$ & 8 \\
\hline 3 & $\begin{array}{c}\text { Almanya, Belçika, } \\
\text { Fransa, İsveç, İtalya, } \\
\text { Japonya }\end{array}$ & $\begin{array}{l}\text { Amerika, } \\
\text { B.Krallık, } \\
\text { Hollanda, } \\
\text { İsviçre, Kanada }\end{array}$ & $\begin{array}{c}\text { (Belçika, B.Krallık) } \\
\text { (Belçika, Hollanda) (Belçika, } \\
\text { İsviçre) (Amerika, Japonya) } \\
\text { (B.Krallık, Hollanda) } \\
\text { (Hollanda, İsviçre) (İsviçre, } \\
\text { Kanada) }\end{array}$ & 7 \\
\hline 4 & $\begin{array}{l}\text { Almanya, Belçika, } \\
\text { B.Krallık, Fransa, } \\
\text { Hollanda, İsveç, } \\
\text { İsviçre, İtalya, Kanada }\end{array}$ & $\begin{array}{l}\text { Amerika, } \\
\text { Japonya }\end{array}$ & $\begin{array}{c}\text { (Belçika, Amerika) (Belçika, } \\
\text { Japonya) (Amerika, } \\
\text { B.Krallık)(Amerika, Hollanda) } \\
\text { (Amerika, İsviçre) (Amerika, } \\
\text { Kanada) }\end{array}$ & 6 \\
\hline 5 & $\begin{array}{l}\text { Almanya, Belçika, } \\
\text { B.Krallık, Fransa, } \\
\text { Hollanda, İsveç, } \\
\text { İsviçre, Kanada }\end{array}$ & $\begin{array}{l}\text { Amerika, } \\
\text { Japonya, İtalya }\end{array}$ & $\begin{array}{c}\text { (Fransa, İtalya) (İsveç, Japonya) } \\
\text { (Japonya, Kanada) (İtalya, } \\
\text { Almanya) }\end{array}$ & 4 \\
\hline 6 & $\begin{array}{c}\text { Almanya, Belçika, } \\
\text { B.Krallık, Hollanda, } \\
\text { İsveç, İsviçre, Kanada }\end{array}$ & $\begin{array}{c}\text { Amerika, } \\
\text { Fransa, } \\
\text { Japonya, İtalya } \\
\end{array}$ & $\begin{array}{l}\text { (B. Krallık, Japonya) (Hollanda, } \\
\text { Japonya) (İsviçre, Japonya) }\end{array}$ & 3 \\
\hline 7 & $\begin{array}{c}\text { Amerika, Belçika, } \\
\text { B.Krallık, Hollanda, } \\
\text { İsveç, İsviçre, Kanada }\end{array}$ & $\begin{array}{c}\text { Almanya, } \\
\text { Fransa, } \\
\text { Japonya, İtalya }\end{array}$ & $\begin{array}{c}\text { (Fransa, İsveç) (Fransa, Almanya) } \\
\text { (İsviçre, İtalya) }\end{array}$ & 3 \\
\hline 8 & $\begin{array}{l}\text { Belçika, B.Krallık, } \\
\text { Fransa, Hollanda, } \\
\text { İsveç, İsviçre, İtalya, } \\
\text { Kanada } \\
\end{array}$ & $\begin{array}{c}\text { Amerika, } \\
\text { Japonya, } \\
\text { Kanada }\end{array}$ & $\begin{array}{c}\text { (Amerika, İsveç) (Hollanda, } \\
\text { Kanada) }\end{array}$ & 2 \\
\hline 9 & $\begin{array}{c}\text { Almanya, Belçika, } \\
\text { Fransa, Japonya, İtalya }\end{array}$ & $\begin{array}{c}\text { Amerika, } \\
\text { B.Krallık, } \\
\text { Hollanda, } \\
\text { İsviçre, İsviçre, } \\
\text { Kanada } \\
\end{array}$ & (B.Krallık, Kanada) & 1 \\
\hline 10 & $\begin{array}{l}\text { Almanya, Amerika, } \\
\text { Belçika, B.Krallık, } \\
\text { Fransa, Hollanda, }\end{array}$ & Japonya, İtalya & (İsveç, İtalya) & 1 \\
\hline
\end{tabular}


Edas Yöntemi ve Kümeleme Analizi İle G-10 ülkelerinin Ekonomik Özgürlük Kriterleri İle Değerlendirilmesi

\begin{tabular}{|c|c|c|c|}
\hline & İsveç, İsviçre, Kanada & & \\
\hline \multirow{4}{*}{11} & Almanya, Amerika, & & \\
Belçika, B.Krallı, & Fransa, Hollanda, \\
& İsveç, İsviçre, Japonya, \\
Kanada & İtalya & (Belçika, İtalya) & 1 \\
\hline
\end{tabular}

Tablo 12'de bazı küme gruplarının sıklığının diğerlerine göre daha fazla ya da az olduğu gözlemlenmiştir. Örneğin 4 kere gözlemlenen küme gruplarından birinde Almanya, Belçika, B. Krallık, Fransa, Hollanda, İsveç, İsviçre, Kanada yer alırken, diğer ülkeler de diğer kümede yer almaktadır. Buradan anlaşılması gereken ise Almanya, Belçika, B.Krallık, Fransa, Hollanda, İsveç, İsviçre, Kanada ülkelerinin ekonomik özgürlük kriterlerine göre daha benzer ülkeler olduğu ve diğer kümede yer alan ülkelerin de birbirine benzer olduğudur. Başka bir örnek verecek olursak Tablo 12'de sıklı̆̆ın en çok yani 19 kere gözlemlendiği küme grubunda Almanya, Belçika, Fransa, İsveç, İtalya ülkeleri aynı grupta yer alırken diğer küme grubunda Amerika, B.Krallık, Hollanda, İsviçre, Japonya, Kanada ülkeleri yer almaktadır.

\subsection{EDAS ve K-Ortalamalar Yöntemlerinden Edilen Bulguların Karşılaştırılması}

İki yöntemden elde edilen bulguları karşılaştırabilmek amaciyla Tablo 13'de G-10 ülkelerinin ekonomik özgürlük kriterleri için EDAS ve k-ortalamalar kümeleme yönteminin uygulama sonuçları sunulmuştur.

Tablo 13: EDAS ve K-ortalamalar Karşılaştırılması

\begin{tabular}{|c|c|c|c|c|}
\hline \multicolumn{2}{|c|}{ EDAS } & \multicolumn{3}{|c|}{ K-Ortalamalar Yöntemi } \\
\hline No & Ülkeler & KÜME 1 & KÜME 2 & Sıklık \\
\hline 1 & Amerika & Almanya, Belçika, Fransa, İsveç, İtalya & $\begin{array}{c}\text { Amerika, B.Krallı, } \\
\text { Hollanda, İsviçre, } \\
\text { Japonya, Kanada }\end{array}$ & 19 \\
\hline 2 & İsveç & $\begin{array}{c}\text { Amerika, Belçika, B.Krallık, Hollanda, } \\
\text { İsveç, İsviçre, Japonya, Kanada }\end{array}$ & Almanya, Fransa, İtalya & 8 \\
\hline 3 & Hollanda & $\begin{array}{c}\text { Almanya, Belçika, Fransa, İsveç, } \\
\text { İtalya, Japonya }\end{array}$ & $\begin{array}{c}\text { Amerika, B.Krallık, } \\
\text { Hollanda, İsviçre, } \\
\text { Kanada }\end{array}$ & 7 \\
\hline 4 & İsviçre & $\begin{array}{l}\text { Almanya, Belçika, B.Krallık, Fransa, } \\
\text { Hollanda, İsveç, İsviçre, İtalya, Kanada }\end{array}$ & Amerika, Japonya & 6 \\
\hline 5 & İtalya & $\begin{array}{c}\text { Almanya, Belçika, B.Krallık, Fransa, } \\
\text { Hollanda, İsveç, İsviçre, Kanada }\end{array}$ & Amerika, Japonya, İtalya & 4 \\
\hline 6 & $\begin{array}{l}\text { Birleşik } \\
\text { Krallık }\end{array}$ & $\begin{array}{c}\text { Almanya, Belçika, B.Krallık, Hollanda, } \\
\text { İsveç, İsviçre, Kanada }\end{array}$ & $\begin{array}{l}\text { Amerika, Fransa, } \\
\text { Japonya, Italya }\end{array}$ & 3 \\
\hline 7 & Belçika & $\begin{array}{c}\text { Amerika, Belçika, B.Krallık, Hollanda, } \\
\text { İsveç, İsviçre, Kanada }\end{array}$ & $\begin{array}{l}\text { Almanya, Fransa, } \\
\text { Japonya, İtalya }\end{array}$ & 3 \\
\hline 8 & Fransa & $\begin{array}{l}\text { Belçika, B.Krallık, Fransa, Hollanda, } \\
\text { İsveç, İsviçre, İtalya, Kanada }\end{array}$ & $\begin{array}{l}\text { Amerika, Japonya, } \\
\text { Kanada }\end{array}$ & 2 \\
\hline
\end{tabular}




\begin{tabular}{|c|c|c|c|c|}
\hline 9 & Kanada & $\begin{array}{c}\text { Almanya, Belçika, Fransa, Japonya, } \\
\text { İtalya }\end{array}$ & $\begin{array}{c}\text { Amerika, B.Krallık, } \\
\text { Hollanda, İsveç, İsviçre, } \\
\text { Kanada }\end{array}$ & 1 \\
\hline 10 & Japonya & $\begin{array}{c}\text { Almanya, Amerika, Belçika, B.Krallık, } \\
\text { Fransa, Hollanda, İsveç, İsviçre, } \\
\text { Kanada }\end{array}$ & Japonya, İtalya & 1 \\
\hline 11 & Almanya & $\begin{array}{c}\text { Almanya, Amerika, Belçika, B.Krallık, } \\
\text { Fransa, Hollanda, İsveç, İsviçre, } \\
\text { Japonya, Kanada }\end{array}$ & İtalya & 1 \\
\hline
\end{tabular}

K-ortalamalar yönteminde en çok karşılaşılan (sıklı̆̆ı en yüksek olan) küme grubu ile EDAS yönteminden elde edilen bulgular incelendiğinde, sıralamada Amerika ile İsveç arka arkaya gelirken, k-ortalamalar yönteminde aynı kümede yer almadığı gözlemlenmiştir. Ancak sıklığı daha az olan başka bir küme grubunda bu ülkeler aynı kümede yer alarak özgürlük kriterlerine göre birbirine benzer ülkeler olduğu sonucuna ulaşılmıştır. Toplam 11 farklı küme grubundan beşinde aynı küme grubu içinde yer almışlardır.

Özarı ve diğerleri (2019) veri seti içinden elde edilen tüm başlangıç merkez seçimi ile oluşacak küme gruplarından hangisinin daha etkin ya da daha iyi ayrılmış olduğunu görülme sıklığına bakılarak karar verilmemesi gerektiğini kurgusal bir çalışmayla göstermişlerdir. $\mathrm{Bu}$ durumda k-ortalamalar kümeleme yöntemi ile elde edilen küme gruplarının hangisinin daha etkin olduğu sonucuna ulaşabilmek için farklı yöntemlerle karşılaştırılarak karar verilmesi, bu çalışmada ise ülkelerin benzerliği incelenirken diğer bilgilerin de önemsenip yorumlanması gerektiği yönündedir.

\section{SONUÇ ve TARTIŞMA}

Çalışmada analiz yöntemi olarak ÇKKV yöntemlerinden biri olan EDAS yöntemi ile Kortalamalardan kümeleme analizi tekniği kullanılmıştır. 2017 y1lı için G-10 ülkelerinin ekonomik özgürlük kriterleri sıralanarak en iyi ve en kötü performansa sahip ülkeler tespit edilmiştir. G-10 ülkelerinin ekonomik performansı değerlendirilmek üzere 12 gösterge içinden iş özgürlügü, işgücü özgürlügü, parasal özgürlük, ticaret özgürlüğü, yatırım özgürlüğü ve finansal özgürlük olmak üzere toplam 6 temel gösterge kullanılmıştır. Burada amaç, EDAS yönteminden elde edilen sonuç ile kümeleme analizinden elde edilen sonucun birbiri ile benzerlik gösterip göstermediğine bakılıp iki yöntemin birbiri ile beraber kullanılıp kullanılmayacağına dair bir sonuca ulaşmaktır.

EDAS yönteminin G-10 ülkelerine uygulanması sonucunda sırasıla en iyi ekonomik özgürlük performansını Amerika, İsveç, Hollanda, İsviçre, İtalya, B. Krallık, Belçika, Fransa, Kanada, Japonya, Almanya ülkeleri göstermiştir. Aynı yıl aynı göstergelerle benzer ülkelerin belirlenmesinde kullanılan k-ortalamalar kümeleme analizinin sonucuna göre ise bu siralamayı sıklığın en çok görüldüğü Almanya, Belçika, Fransa, İsveç, İtalya ülkeleri aynı kümede yer alırken Amerika, B.Krallık, Hollanda, İsviçre, Japonya, Kanada ülkeleri ise bir grup içerisinde yer almıştır. Özetle, EDAS yönteminde ilk sırayı Amerika ve İsveç ülkeleri alırken kümeleme analizinde ise bu iki ülke farklı küme grupları içerisinde yer almıştır. Elde edilen bulgulardan hareketle ilk yöntemin sıralamasında peş peşe yer alan bazı ülkelerin k-ortalamalar yönteminde 
oluşan kümelerde aynı kümede yer almadıkları yani birbirine daha az benzedikleri sonucuna varılmıştır.

\section{KAYNAKLAR}

Arslan, F.M. (2004). Spor Ayakkabısı Satın Alma ve Kullanım Amaçlarına İlişkin Pazar Bölümlerinin Oluşturulması: Üniversite Öğrencileri Üzerine Bir Araştırma, Marmara Üniversitesi İ̈BF Dergisi, 19(1), ss. 251-276.

Aşan, Z. (2007). Kredi Kartı Kullanan Müşterilerin Sosyo-Ekonomik Özelliklerinin Kümeleme Analiziyle İncelenmesi, Dumlupınar Üniversitesi Sosyal Bilimler Dergisi, Nisan (17), ss. 256-268

Burn, D. H., Zrinji, Z., and Kowalchulk, M. (1997). Regionalization of Catchments for Regional Flood Frequency Analysis. Journal of Hydrologic Engineering, 2(2), 76-82.

Cebeci, Z., Yıldız, F., Kayaalp, G.T. (2015). K-Ortalamalar Kümelemesinde Optimum K Değeri Seçilmesi, 2. Ulusal Yönetim Bilişim Sistemleri Kongresi, 8-10 Ekim 2015, Erzurum. Bildiriler Kitabı (Ed: Ü. Özen ve ark.), s. 231-242. Orka Ofset Matbaac1lı, Erzurum, ISBN:978-975-442-738-7.

Çelik, M., (2015). Yükselen Ekonomilerde Ekonomik Özgürlük - Doğrudan Yabancı Yatırım İlişkisi: Panel Veri Analizi (1995 - 2013), Adnan Menderes Üniversitesi Sosyal Bilimler Enstitüsü İktisat Anabilim Dalı, Aydın, 2015-YL-057

Çelik, Ş. (2013). Kümeleme analizi ile sağlık göstergelerine göre Türkiye'deki illerin sınıflandırılması. Doğuş Üniversitesi Dergisi, 14 (2), 175-194.ss.

Demirel, M.C. (2004). Cluster Analysis of Streamflow Data over Turkey. Master of Science Thesis. İstanbul Technical University, 119p.

Demirel, M.C., Mariano, A.J., Kahya, E. (2007). Performing K-Means Analysis to Drought Principal Components of Turkish Rivers. Hydrology days, 145-151.

Ersöz, F., \& Kabak, M. (2010). Savunma Sanayi Uygulamalarında Çok Kriterli Karar Verme Yöntemlerinin Literatür Araştırması. Savunma Bilimleri Dergisi, 9(1), 97-125.

Isik, S., Singh, V.P., (2009). Hydrologic Regionalization of Watersheds in Turkey. Journal of Hydrologic Engineering. 13(9), 824-834.

Kahya, E., Demirel, M.C., Piechota, T.C. (2007). Spatial Grouping of Annual Streamflow Patterns in Turkey. Hydrology Days, 169-176.

Kalaycı, Ş. (2009), SPSS Uygulamalı Çok Değişkenli İstatistik Teknikleri, 4. Baskı, Ankara: Asil Yayın Dağıtım.

Karabasevic, D., Zavadskas, E. K., Stanujkic, D., Popovic, G., \& Brzakovic, M. (2018). An Approach To Personnel Selection In The It Industry Based On The EDAS Method. Transformations in Business \& Economics, 17(2).

Karaşan, A., and Kahraman, C. (2019). A novel intuitionistic fuzzy DEMATEL-ANP-TOPSIS integrated methodology for freight village location selection. Journal of Intelligent \& Fuzzy SystemsPreprint. 1-18. 
Karypis, M. S. G., Kumar, V., \& Steinbach, M. (2000, August). A comparison of document clustering techniques. In TextMining Workshop at KDD2000 (2000).

Keshavarz Ghorabaee, M., Zavadskas, E. K., Olfat, L., \& Turskis, Z. (2015). Multi-criteria inventory classification using a new method of evaluation based on distance from average solution (EDAS), Informatica, 26(3), s. 435-451.

Liu, Y., Li, Z., Xiong, H., Gao, X. \& Wu, J. (2010). Understanding of Internal Clustering Validation Measures. 2010 IEEE Int. Conf. on Data Mining, 911-916.

Lin, G-F., Chen, L-H. (2006). Identification of Homogeneous Regions for Regional Frequency Analysis using the Self-Organizing Map. Journal of Hydrology, 324, 1-9..

Fırat, M., Dikbaş, F., Koç, A.C., Güngör, M. (2012). K-Ortalamalar Yöntemi ile Yıllık Yağışların Sınıflandırılması ve Homojen Bölgelerin Belirlenmesi, İMO Teknik Dergi, 6037-6050, Yaz1 383.

Özarı, Ç., Eren, Özge, \& Alıcı, A. (2019). K-Ortalamalar Yönteminin Başlangıç Merkez Seçim Sorunsalı Üzerine Bir Çalışma. Business \& Management Studies: An International Journal, 7(2), 1117-1135.

Özbek, A., \& Engür, M. (2018). EDAS Yöntemi ile Lojistik Firma Web Sitelerinin Değerlendirilmesi. Selçuk Üniversitesi Sosyal Bilimler Meslek Yüksekokulu Dergisi, 21(2), 417-429.

Özbek, A. (2019). Türkiye'deki İllerin EDAS Ve WASPAS Yöntemleri ile Yaşanabilirlik Kriterlerine Göre Sıralanması. Kırıkkale Üniversitesi Sosyal Bilimler Dergisi, 9(1), $177-200$

Stanujkic, D., Zavadskas, E. K., Ghorabaee, M. K., \& Turskis, Z. (2017). An extension of the EDAS method based on the use of interval grey numbers. Studies in Informatics and Control, 26(1), 5-12.

Stević, Ž., Pamučar, D., Vasiljević, M., Stojić, G., \& Korica, S. (2017). Novel integrated multicriteria model for supplier selection: Case study construction company. Symmetry, 9(11), 279.

Turan, A.,(2005). Türkiye Akarsu Verimlerinin Küme Analizi ile Sinıflandırılması. Sakarya Üniversitesi, Fen Bilimleri Enstitüsü Yüksek Lisans Tezi, 155s.

Ulutaş, A. (2017). EDAS yöntemi kullanılarak bir tekstil atölyesi için dikiş makinesi seçimi. İşletme Araştırmaları Dergisi, 9(2), 169-183.

Ulutaş, A. (2018). ENTROPİ Tabanlı EDAS Yöntemi ile Lojistik Firmalarının Performans Analizi. Uluslararası İktisadi ve İdari İncelemeler Dergisi, (23), 53-66.

Yüksel, C.A. (2002). Dondurulmuş Hazır Yemek Satın Alan Tüketicilerin Özelliklerini Belirlemeye Yönelik Araştırma, Ege Akademik Bakış Dergisi, 2(1), s.1-12. 